\title{
PSICHIKOS SVEIKATOS PAGALBOS PO EKSTREMALIŲJŲ IVYKIŲ SVARBA
}

\author{
Birutė Pitrènaitė-Žilènienė \\ Mykolo Romerio universiteto Politikos ir vadybos fakultetas \\ Vadybos institutas \\ Valakupių g. 5, LT-10101 Vilnius, Lietuva \\ Telefonas (+370 5) 2740610 \\ Elektroninis paštas birute.pitrenaite@mruni.eu

\section{Vilma Miglinė} \\ Vilniaus miesto savivaldybès visuomenès sveikatos biuras \\ Polocko g. 12-2, LT-01204 Vilnius, Lietuva \\ Telefonas (+370 5) 2711244 \\ Elektroninis paštas vilma.migline@gmail.com \\ Pateikta $2015 \mathrm{~m}$. vasario $23 \mathrm{~d}$., parengta spausdinti $2015 \mathrm{~m}$. balandžio $7 \mathrm{~d}$.
}

DOI:10.13165/SPV-15-1-8-04

\section{Santrauka}

Prognozuojama, kad per ateinančius dešimtmečius Europa neišvengiamai patirs labai svarbiu gamtiniu ir socialinių sukrètimu, dèl kuriu galimi ženklūs visuomenés gerovés, fizinès ir psichines sveikatos sutrikimai. Todèl svarbu tinkamai tam pasiruošti, ugdant gebẻjima efektyviai prisitaikyti prie greitai kintančiu saugumo sąlygų. Dèl geofizines situacijos pokyčiu siektinas tikslas bütu sukurti atsparias visuomenes, kurios gebètu neutralizuoti bet kokio sukrètimo poveiki ir laiku atsigauti po jo. Karas, ginkluoti konfliktai, gamtines bei technologinès katastrofos turi didele psichologine ir socialine ịtaka paveiktai populiacijai. Po kiekvieno pavoju sukèlusio įvykio emocinę trauma patiria daug žmonių. Stipru emocinį sukrètima gali patirti ne tik fiziškai dalyvavusios ìvykyje ir / ar patyrusios fizines traumas aukos, bet ir ju artimieji ar net tiesiogiai su ìvykiu nesusije asmenys.

Šio straipsnio tikslas - atlikus mokslinès literatūros ir praktiniu pavyzdžiu analize, nustatyti ekstremaliojo ịvykio poveikio bei rizikos veiksniu ịtaka nukentëjusiuju ir pagalba teikiančiųu psichikos sveikatai ir pagristi prevenciniu priemoniu planavimo bütinybę. 
Tyrimai rodo, kad vienas dažniausiu psichikos sveikatos po ekstremaliojo įvykio sutrikimu yra potrauminio streso sindromas, kurio išsivystyma lemia įvairūs rizikos veiksniai. Tarp ju labai svarbūs yra socialiniai veiksniai. Psichologiniam atsparumui didele įtakq daro suvokimas, kad susidarius ekstremaliajai situacijai žmonems visokeriopa pagalba suteiks ne tik artimieji, bet ir kompetentingos institucijos tinkamai pasirūpins fizinio ir psichologinio komforto atkürimu. Todèl i ekstremaliuju situaciju valdymo (ESV) planus turi büti įtrauktos ne tik fizinès pagalbos teikimo priemones, bet ir numatyti psichosocialiniai aspektai.

Ivertinus tai, kad prognozuojant sudetinga numatyti galimu ekstremaliuju situaciju charakteristikas ir padarinius, svarbu, kad ESV planai bütų lankstūs, patikrinti ir nuolatos atnaujinami. Asmenys, kurie dalyvaus veiksmuose atsakant i ekstremaliuosius ivykius, privalo turèti aišku supratima apie savo vaidmenį. Planuojant atsako į ekstremaliuosius įvykius priemones, bütina užtikrinti psichikos sveikatos tarnybu prieinamuma ir psichosocialine parama nukentejjusioms bendruomenems, atsižvelgiant ị psichikos sveikatos sutrikimu ǐssivystymą lemiančius rizikos veiksnius. Todèl tikslinga sudaryti ilgalaikę bendruomenés psichikos sveikatos priežiūros sistema po ekstremaliuju įvykių.

Reikšminiai žodžiai: psichikos sveikata, ekstremaliosios situacijos, potrauminio streso sindromas, rizikos veiksniai, stresoriai, prevencija.

\section{Ivadas}

Per ateinančius dešimtmečius Europa neišvengiamai patirs labai svarbiụ gamtinių ir socialinių sukrètimų. Prognozuojama, kad $2080 \mathrm{~m}$. dèl klimato pokyčiu galimi ženklūs visuomenès gerovès ir sveikatos sutrikimai, jeigu tam nebus tinkamai pasiruošta ${ }^{1}$. Šiame kontekste svarbiausia bus gebėti efektyviai prisitaikyti prie greitai kintančio pasaulio. Dèl geofizinès situacijos pokyčių siektinas tikslas būtų sukurti atsparias visuomenes. Tokios visuomenès turi gebėti neutralizuoti bet kokio sukrètimo poveikị ir laiku atsigauti po jo ${ }^{2}$. Taip šios visuomenès tampa saugesnès.

Kasmet milijonai žmonių pasaulyje susiduria su nelaimingais atsitikimais, ginkluotais konfliktais, technologinèmis bei gamtinemis katastrofomis, o per juos išgyvenusieji patiria didelę grèsmę gyvybei, sunkias traumas, netenka artimųjų, bendruomenės narių, turto, namų, daiktų. Taip pat prie šio streso prisideda nutrūkusio bendravimo su šeima problemos, nuovargis ir miego sutrikimai, alkis, emocinè ir fizinè įtampa. Gamtinès kilmès nelaimès gali sunaikinti ištisas gyvenamąsias vietoves, kuriose žmonès gyveno nuo gimimo. Nepriklausomai

Ciscar, J. C.; Iglesias, A.; Feyen, L., et al. 2011. Physical and Economic Consequences of Climate Change in Europe. Proceedings of the National Academy of Sciences of USA. 108: 2678-2683.

2 United Nations: Rio Declaration: Rio+20 - The Future We Want. 2012. Rio de Janeiro: Rio 20 United Nations Conference on Sustainable Development. 
nuo nelaimės pobūdžio neigiamai paveikiamas didelis žmonių skaičius, o tai gali lemti ženklias socialines permainas.

Pavoju gyvybei, sveikatai ir / ar turtui sukeliantys ịvykiai turi didelę psichologinę ir socialinę įtaką nukentèjusiai populiacijai. Po kiekvieno ekstremaliojo įvykio (EI) atsiranda emocinę traumą patyrusių aukų. Kad būtų stipriai paveiktos, šios aukos nebūtinai turi fiziškai dalyvauti pačiame ịvykyje. El aukas galima būtų skirti ị dvi grupes: tiesiogines ir netiesiogines. Tiesioginès aukos - tai tiesiogiai ịvykyje dalyvavusieji, žuvusieji, sužeistieji, internuotieji ar kitaip nukentèję žmonès. Netiesioginèms aukoms priskiriami tiesioginių aukų giminaičiai, draugai, EI liudininkai, kurie patys nepatyrẻ fizinių sužalojimų. Svarbu paminėti, kad net ir toli nuo įvykio vietos esanti likusi populiacijos dalis gali taip pat būti paveikta dèl informacijos sklaidos per žiniasklaidos priemones.

Vienas dažniausių psichikos sveikatos po EI sutrikimų yra potrauminio streso sindromas (PTSS). Tai būklè, apibūdinama individualiais išgyvenimais ar liudijimais po traumą sukeliančio ịvykio ar ịvykių, kurie yra arba gresia būti mirties arba rimto pažeidimo priežastis sau arba kitiems ir sukelia intensyvų pavojaus, baimès, bejejgiškumo jausmą su po to pasireiškiančiais įsibrovimo, vengimo, didelio susijaudinimo simptomais ${ }^{3}$.

Kaip parodè tyrimai po dešimt didžiųjų EI, PTSS patiria vidutiniškai 20 proc. išgyvenusiųjų ${ }^{4}$. Po EI i i pasekmių likvidavimą įsitraukia daugybè tarnybų ir jose dirbančių žmonių, kurių psichikos sveikatai taip pat iškyla grèsmè. Didelio masto nelaimès lauke dirba ịvairios gelbètojų grupès: gaisrininkai, policininkai, statybininkai, medikai, paramedikai, savanoriai, paieškos ir gelbejimo tarnybų personalas ${ }^{5}$. Idomu, kad pagalbos teikëjams PTSS dažnis labai svyruoja - nuo 7 proc. tarp policinink $u^{6}$ iki 46 proc. tarp savanorių ${ }^{7}$. Neseniai atliktų 28 tyrimų su ịvairių rūšių gelbètojais metaanalizė parodè, kad PTSS nustatomas vidutiniškai 10 proc. visų gelbejimo darbuose dalyvaujančių asmenų. Itvairiais moksliniais tyrimais nustatyta, jog traumuojamoji patirtis gali būti perduodama

American Psychiatric Association. 2013. The Diagnostic and Statistical Manual of Mental Disorders: DSM 5. Bookpoint US.

4 North, C. S.; Oliver, J.; Pandya, A. 2012. Examining a comprehensive model of disaster-related posttraumatic stress disorder in systematically studied survivors of 10 disasters. American Journal of Public Health. 102(10): e40-e48.

5 Penalba, V.; McGuire, H.; Leite, J. R. 2008. Psychosocial Interventions for Prevention of Psychological Disorders in Law Enforcement Officers. Cochrane Database of Systematic Reviews. 3.

6 Maia, D. B.; Marmar, C. R.; Metzler, T., et al. 2007. Post-traumatic Stress Symptoms in an Elite Unit of Brazilian Police Officers: Prevalence and Impact on Psychosocial Functioning and on Physical and Mental Health. Journal of Affective Disorders. 97(1): 241-245.

7 Mitchell, T. L.; Griffin, K.; Stewart, S. H., et al. 2004. We Will Never Ever Forget: The Swissair Flight 111 Disaster and its Impact on Volunteers and Communities. Health Psychology. 9(2): 245-62.

8 Berger, W.; Coutinho, E. S.; Figueira, I., et al. 2012. Rescuers at Risk: A Systematic Review and Meta-regression Analysis of the Worldwide Current Prevalence and Correlates of PTSD in Rescue Workers. Social Psychiatry and Psychiatric Epidemiology. 47(6): 1001-1011. 
iš kartos ị kartą9 . Taip pažeidžiama karta, kuri net nebuvo tiesiogiai susidūrusi su EĮ. Taigi ekstremaliųjų situacijų sukeltos psichologinès ir socialinès pasekmès gali ilgam neigiamai paveikti populiacijos psichikos sveikatą ir psichosocialinę gerovę. Todèl $2012 \mathrm{~m}$. Pasaulio sveikatos organizacijos (PSO) asamblejoje priimtoje rezoliucijoje WHA 65.4 „Dèl psichikos sutrikimų globalinės reikšmès“ psichikos sveikatai užtikrinti pabrèžiama būtinybe kiekvienai šaliai turèti sveikatos ir socialinio sektoriaus koordinuotą veiksmų planą ${ }^{10}$, paskirti tarnybas, užtikrinančias psichologinę paramą po Eț ${ }^{11}$.

Šio straipsnio tikslas - nustatyti ekstremaliojo įvykio poveikio bei rizikos veiksnių neigiamą įtaką nukentėjusiųjų psichikos sveikatai ir pagrịsti prevencinių bei pagalbos priemonių planavimo būtinybę. Tikslui pasiekti nustatyti šie uždaviniai:

- išanalizuoti psichikos sveikatos ypatumus per ir po ekstremaliojo ịvykio;

- identifikuoti pagrindinius rizikos veiksnius ir stresorius, lemiančius psichikos sveikatos sutrikimus;

- išanalizuoti mokslininkų ir tarptautinių organizacijų rekomendacijas dèl psichikos sveikatos sutrikimų prevencijos ir psichikos sveikatos paslaugu EI metu ir po jų;

- apibendrinus analizès rezultatus pateikti siūlymus psichikos sveikatos pagalbos planavimui tobulinti.

Uždaviniams ịgyvendinti taikytas mokslinès literatūros, tarptautinių organizacijų strateginių ir rekomendacinio pobūdžio dokumentų, praktinių pavyzdžių analizès metodas.

\section{Psichikos sveikata ir rizikos veiksniai po ekstremalaus ịvykio}

Psichikos sveikata yra bendrosios žmogaus sveikatos pagrindas. Kiekvienas žmogus savo gyvenime susiduria su ịvairiomis stresinėmis situacijomis. Gyvenimo vystymosi cikle žmogų nuolatos lydi stresiniai gyvenimo ịvykiai, tokie kaip brolių ar seserų gimimas, ankstyva tėvų mirtis, atskyrimas nuo šeimos, skyrybos šeimoje, senejimas, hospitalizacija, sunkios ligos diagnozė, išejimas ị pensiją ir daugybė kitų. Greta to žmogų nepalankiai gali veikti patirtos gamtinès katastrofos, žmogaus sukeltos tyčinès ar netyčinès nelaimès ir smurtiniai išpuoliai. Kiekvieno žmogaus atsakas ị patirtą stresą priklauso nuo asmeninių (psichologinių, pažintinių, elgesio, emocinių, egzistencinių, dvasinių) savybių.

Yehud, R.; Hallig, S. L.; Grossman, R. 2001. Childhood Trauma and Risk for PTSD: Relationship to Intergenerational Effects of Trauma, Parental PTSD, and Cortisol Excretion. Development and Psychopathology. 13: 733-753.

10 World Health Organization. 2012. Global Burden of Mental Disorders and the Need for a Comprehensive, Coordinated Response from Health and Social Sectors at the Country Level.

11 World Health Organization. 2013. Mental Health Action Plan 2013-2020. 
Žmogaus organizmas natūraliai igimtais mechanizmais kovoja su patirtu stresu, ir dauguma tokių reakcijų praeina savaime. Vis dèlto kai kurios jų užsitęsia, vystosi grèsmingos pasekmès psichikos sveikatai - tuomet būtina gydyti. Kokia bus žmogaus reakcija ị stresą ir kaip jis susidoros su juo, priklauso nuo daugybės buvusių jau prieš patiriant stresinị ịvykị, streso metu ir po jo veikusių veiksnių.

Kai kuriems išgyvenusiesiems po ekstremaliojo įvykio gali išsivystyti potrauminio streso sindromas, depresija ar nerimas. Moksliniais tyrimais nustatyta, jog PTSS yra susijęs su padidejusiu bendruoju mirtingumu ir sergamumu ìvairiomis lètinèmis ligomis ir prisitaikymo sutrikimais ${ }^{12}$. Būtent todèl po didelio masto katastrofų labai svarbu identifikuoti asmenis, turinčius padidejjusią psichikos sveikatos sutrikimų riziką, diagnozuoti šiuos sutrikimus ir juos gydyti.

\subsection{Potrauminio streso sindromo epidemiologija po ekstremaliojo ịvykio}

Nemažai epidemiologinių PTSS tyrimų atlikta Šiaurès Amerikoje, Australijoje, kur PTSS dažnis bendrojoje populiacijoje siekè 6,8 proc. ${ }^{13},{ }^{14}$. Europoje tokių tyrimų būta mažiau. Vienas didesnių tyrimų atliktas $2008 \mathrm{~m}$. mokslininko J. M. Darves-Bornozo ir bendraautorių ${ }^{15}$. Buvo tiriamas PTSS dažnis bendrojoje populiacijoje šešiose Europos šalyse: Belgijoje, Italijoje, Ispanijoje, Olandijoje, Prancūzijoje ir Vokietijoje. Naudojant Pasaulio sveikatos organizacijos kompleksinị tarptautinị diagnostinị klausimyną, 2000 (angl. The Composite International Diagnostic Interview - CIDI, 2000), ištirta beveik 9000 asmenų. PTSS dažnis svyravo nuo 2,63 proc. Olandijoje iki 0,56 proc. Ispanijoje.

Mokslininkas S. Galea ir bendraautoriai $2005 \mathrm{~m}$. apžvelge MEDLINE, PsychINFO ir PILOTS duomenų bazèse publikuotus tyrimus apie PTSS epidemiologiją tarp patyrusiųjų EI nuo 1963 m. žemès nuošliaužos Šiaurès rytų Italijoje iki $2001 \mathrm{~m}$. rugsèjo vienuoliktosios teroristinio išpuolio Niujorke ${ }^{16}$. Po žmogaus sukeltų technologinių nelaimių PTSS dažnis siekè nuo 25 iki 75 proc. per pirmuosius metus po įvykio. Tarp asmenų, dirbusių gelbejjimo operacijose, PTSS pasireiškimo po nelaimès dažnis svyravo nuo 5 iki 40 proc. PTSS daž-

12 Boscarino, J. A. 2008. Prospective Study of PTSD and Early-age Heart Disease Mortality among Vietnam Veterans: Implications for Surveillance and Prevention. Psychosomatic Medicine. 70: 668.

13 Kessler, R. C.; Berglund, P.; Delmer, O., et al. 2005. Lifetime prevalence and age-of-onset distributions of DSM-IV disorders in the National Comorbidity Survey Replication. Archives of General Psychiatry. 62(6): 593-602.

14 Creamer, M.; Burgess, P.; McFarlane, A. C. 2001. Post-traumatic Stress Disorder: Findings from the Australian National Survey of Mental Health and Well-being. Psychological Medicine. 31(07): 1237-1247.

15 Darves-Bornoz, J. M.; Alonso, J.; de Girolamo, G., et al. 2008. Main Traumatic Events in Europe: PTSD in the European Study of the Epidemiology of Mental Disorders Survey. Journal of Traumatic Stress. 21(5): 455-462.

16 Galea., S.; Nandi, A.; Vlahov, D. 2005. The Epidemiology of Post-Traumatic Stress Disorder after Disasters. Oxford Journals Medicine Epidemiologic Reviews. 27(1): 78-91. 
niausiai išsivysto per pirmuosius metus po EIt, o praejjus 18 mėnesių laipsniškai ima mažèti. Vèlesnę PTSS simptomų eigos trajektoriją lemia daugelis veiksnių: efektyvi psichikos sveikatos intervencija ankstyvosiose stadijose po EI , nukentéjusiųjų socialinė aplinka, individualus gebejjimas prisitaikyti ir kiti ${ }^{17}$.

\subsection{Rizikos veiksniai ir stresoriai psichikos sutrikimams išsivystyti po ekstremaliojo įvykio}

Potrauminio streso sindromui išsivystyti labai svarbus ne tik pats EIt, bet ir rizikos veiksniai. Šiuo klausimu yra atlikta nemažai tyrimų. Nustatyti reikšmingiausi rizikos veiksniai: moteriškoji lytis, kaltès jausmas, pyktis, silpnesni gebejjimai prisitaikyti, anksčiau patirti traumuojamieji ìvykiai, psichikos ligu anamnezè, socialinės paramos nebuvimas, blogi tarpusavio ryšiai su kitais šeimos nariais ar bendradarbiais, žiniasklaidos ittaka ${ }^{18}$. Daugeliu tyrimų nustatyta ir EI poveikio (ekspozicijos) stiprumo įtaka. Ilgiau trunkantys EI susiję su didesniu PTSS pasireiškimo dažniu ${ }^{19}$. Taip pat minima žemesnès socialinès ir ekonominès padèties, amžiaus, rasės ar etninès grupès ir ịsidarbinimo padèties (dirba žmogus ar ne) įtaka PTSS raiškai ${ }^{20}$.

Mokslininkų L. M. Duke ir J. J. Vasterlingo ${ }^{21} 2005$ m. atliktame tyrime išskirti rizikos veiksniai, kurie turi itakos - išsivystys ar ne - traumuotam asmeniui lètinè PTSS forma, gali būti skiriami į tris kategorijas:

1) veiksniai, susiję su pačiu Tİ: traumos pobūdis, intensyvumas;

2) individualios asmens savybės: amžius, lytis, intelektas, socioekonominė padètis, psichikos sveikatos sutrikimų ir bendra medicininè anamnezé, asmenybès tipas;

3) peritrauminiai ir potrauminiai veiksniai: suvokta grèsmė savo gyvybei, peritraumine disociacija, biologinis bei emocinis atsakas ị traumą.

Nuo visų šių veiksnių sąveikos traumuotam asmeniui: a) išsivysto PTSS, b) išsivysto simptomai, kurie neatitinka PTSS diagnostikos kriterijų, arba c) žmogus visiškai pasveiksta, jo fizinė bei psichikos sveikata yra patenkinama.

17 Wang, C. W.; Chan, C. L.; Ho, R. T. 2013. Prevalence and Trajectory of Psychopathology among Child and Adolescent Survivors of Disasters: a Systematic Review of Epidemiological Studies across 1987-2011. Social Psychiatry and Psychiatric Epidemiology. 48(11): 1697-1720.

18 Ahern, J.; Galea, S.; Resnick, H., et al. 2002. Television Images and Psychological Symptoms after the September 11 Terrorist Attacks. Psychiatry. 65: 289-300.

19 Green, B. L.; Lindy, J. D.; Grace, M. C., et al. 1990. Buffalo Creek Survivors in the Second Decade: Stability of Stress Symptoms. American Journal of Orthopsychiatry. 60: 43-54.

20 Trautman, R.; Tucker, P.; Pfefferbaum, B., et al. 2002. Effects of Prior Trauma and Age on Posttraumatic Stress Symptoms in Asian and Middle Eastern Immigrants after Terrorism in the Community. Community Mental Health Journal. 38: 459-74.

${ }^{21}$ Duke, L. M.; Vasterling, J. J. 2005. Epidemiological and Methodological Issues in Neuropsychological Research in PTSD. In: Vasterling, J.J., Brewin, C.R. (Eds.) Neuropsychology of PTSD: Biological, Cognitive, and Clinical Perspective. New York: The Guilford Press. 
Ivairias stresines situacijas laikinai patiria dauguma žmonių, vẻliau prasideda adaptacijos periodas ir galiausiai - grižimas ị ịprastą būseną. Gana sunku nubrèžti ribą tarp normalaus atsako ị EI ir tarp atsako, kuris lemia psichikos sveikatos sutrikimus. Šiems ịtakos turi susipynę pirminiai ir antriniai stresoriai ${ }^{22}$. Pirminiai stresoriai - tai tiesiogiai ekstremaliosios situacijos sukelti stresoriai. Antriniai stresoriai - tai būklès ar ịvykiai, kurie nèra tiesiogiai susiję su EI , ir šie paprastai užtrunka ilgiau. Kai kurie jų yra savarankiški, o kai kurie - užsitęsę, tokie kaip infrastruktūros sutrikimai po EĮ ir kt. (žr. 1 lentelę). Gausu įrodymų, jog tikimybe išsivystyti psichikos sveikatos sutrikimams dideja augant pirminių ir antrinių stresorių intensyvumui bei jiems trunkant ilgą laiką.

1 lentelè. Pirminiai ir antriniai stresoriai

\begin{tabular}{|c|c|}
\hline Pirminiai stresoriai & Antriniai stresoriai \\
\hline Fizinis sužalojimas & $\begin{array}{l}\text { - Hospitalizacija } \\
\text { - Operacija } \\
\text { - Atskyrimas nuo tėvų (pvz., vaikams hospitalizacijos metu) } \\
\text { - Itprastos rutinos netekimas } \\
\text { - Darbo netekimas } \\
\text { - Socialinio gyvenimo netekimas } \\
\text { - Nerimas dèl sveikatos } \\
\text { - Sveikatos priežiūros stoka } \\
\text { - Sunkumai, susiję su finansinių kompensacijų išmokèjimu }\end{array}$ \\
\hline $\begin{array}{l}\text { Gamtiniai EI } \\
\text { (uraganai, štormai, } \\
\text { tornadai, potvyniai, } \\
\text { žemės drebejimai, } \\
\text { cunamiai) }\end{array}$ & $\begin{array}{l}\text { - Evakuacija } \\
\text { - Pastogės netekimas } \\
\text { - Mokyklų uždarymas } \\
\text { - Sugriautos darbovietės } \\
\text { - Materialinių vertybių praradimas } \\
\text { - Atskyrimas nuo artimųjų } \\
\text { - Darbo netekimas } \\
\text { - Gyvenimas laikinose prieglaudose } \\
\text { - Bendruomenės praradimas } \\
\text { - Problemos, susijusios su namų atstatymu } \\
\text { - Resursų trūkumas } \\
\text { - Ekonominės problemos } \\
\text { - Sunkumai, susiję su finansinių kompensacijų išmokejjimu } \\
\text { - Gyvybiškai svarbių paslaugų stoka }\end{array}$ \\
\hline
\end{tabular}

22 Lock, S.; Rubin, G. J.; Murray, V., et al. 2012. Secondary Stressors and Extreme Events and Disasters: a Systematic Review of Primary Research from 2010-2011. PLoS Currents. 4. 


\begin{tabular}{|l|l|}
\hline & - Vietovès stigmatizacija \\
& - Evakuacija \\
Technologinio & - Priverstinis persikraustymas ị kitą vietą \\
pobūdžio EI & - Gyvenimas laikinose prieglaudose \\
(branduolinių, & - Ekonominès problemos \\
cheminių, biolo- & - Sunkumai, susiję su finansinių kompensacijų išmokèjimu \\
ginių medžiagų & - Darbo netekimas \\
pasklidimas) & - Bendruomenès netekimas \\
& - Verslų bei mokyklų uždarymas \\
& - Baimè susirgti onkologine liga \\
& - Ilgalaikis poveikis sveikatai
\end{tabular}

S. Lockas ir bendraautoriai $2012 \mathrm{~m}$. straipsnyje apžvelgia 253 tyrimus, spausdintus 2010-2011 m. (naudojantis MEDLINE, Embase ir PychINFO duomenu bazėmis), nagrinejjančius antrinius stresorius po ekstremaliųjų ívykių ${ }^{23}$. Jie antrinius stresorius suskirste $i$ šías grupes:

1) ekonominiai stresoriai - tai stresas, atsirandantis praradus santaupas ar netekus darbo, pajamų, stokojant finansinès paramos. Šio stresoriaus poveikis nustatomas jau nuo 10 sav. po Et ir tęsiasi iki 32 mèn. ${ }^{24}$;

2) stresas, susijęs su problemomis, kylančiomis sprendžiant kompensacijų išdavimo klausimus. Dažniausiai tai būna draudimo ar finansinių išmokų klausimai. Žmonès mažai išmano kreipimosi dèl kompensacijos tvarkos procedūras, institucijų vaidmenis ir atsakomybę. Ypač neigiamai veikia, jei kreipimasis dèl kompensacijos net nebuvo nagrinètas, užtruko ar buvo atmestas ${ }^{25},{ }^{26}$;

3) stresas, susijęs su pastatų atstatymu. Traumuojamąji poveikị psichikos sveikatai turi gyvenimas laikinose prieglaudose (stovyklose, bendrabučiuose). Pagalbos stoka atstatant namus kai kuriuos žmones veikia kaip stiprus stresorius ${ }^{27}$;

4) stresas, sukeltas netekus nuosavybès. Dauguma nukentejusiųjų per EI praranda automobilius, namų apyvokos daiktus, drabužius. Užsitęsęs šių daiktų igijimo periodas taip pat turi neigiamą poveikị nukentẻjusiojo psichikos sveikatai ${ }^{28}$;

23 Lock, S., et al, supra note 20, p. 4.

24 Ehrlich, M.; Harville, E.; Xiong, X., et al. 2010. Loss of Resources and Hurricane Experience as Predictors of Postpartum Depression Among Women in Southern Louisiana. Journal of Women's Health. 19(5): 877-884.

25 Wind, T. R.; Fordham, M.; Komproe, I. H. 2011. Social Capital and Post-Disaster Mental Health. Global Health Action. 4: 1654-9880.

26 Carroll, B.; Balogh, R.; Morbey, H., et al. 2010. Health and Social Impacts of a Flood Disaster: Responding to Needs and Implications for Practice. Disasters. 34(4): 1045-63.

27 Wickrama, K. A. S.; Wickrama T. 2011. Perceived Community Participation in Tsunami Recovery Efforts and the Mental Health of Tsunami-Affected Mothers: Findings from a Study in Rural Sri Lanka. International Journal of Social Psychiatry. 57(5): 518-27.

28 Zhang, Z.; Shi, Z.; Wang, L., et al. 2011. One Year Later: Mental Health Problems among Survivors in Hard-Hit Areas of the Wenchuan Earthquake. Public Health. 125(5): 293-300. 
5) su sveikatos būkle susiję stresoriai. Antriniams stresoriams priskiriami rūpesčiai dèl savo ar artimųjų sveikatos, medicinos pagalbos teikimo ar vaistų prieinamumo ${ }^{29},{ }^{30}$;

6) stresas, susijęs su švietimo įstaigomis. Kai kurie tyrimai atskleidžia neigiamą poveikị psichikos sveikatos būklei, jeigu reikia keisti mokyklą ar universitetą ${ }^{31}$;

7) stresas, susijęs su situacijos pateikimu žiniasklaidoje. Labai intensyvus EI nušvietimas žiniasklaidoje gali būti susijęs su padidejjusia psichikos sveikatos sutrikimų rizika ${ }^{32}$;

8) šeimoje kylantys stresoriai. Šeimos funkcionavimo pokyčiai gali būti problemiški. Antriniams stresoriams priskiriama santykių nutraukimas, sumažejusi partnerio socialinè parama, konfliktai tarp tèvų, pakitusi santuokiné padètis ir sumažejęs intymumas tarp partnerių ${ }^{33}$;

9) neigiamai psichikos sveikatą veikia ir tokie socialiniai stresoriai kaip nutrūkę santykiai su draugais, bendradarbiais ${ }^{34}$;

10) stresoriai, atsirandantys netekus ịprastų laisvalaikio užsièmimų. Miego trūkumas, nelikę laisvalaikio užsièmimai taip pat gali prisidèti prie psichikos sveikatos sutrikimų ${ }^{35}$;

11) pasaulěžiūros ir savivokos sukeltas stresas. Sumažėjęs nepriklausomybės jausmas, sumenkèjusi savivertè, prarasti tikejjimas ateitimi ir tikslai - dažnai po EI pasitaikantys antriniai stresoriai ${ }^{36}$.

29 Ehrlich, M.; Harville, E.; Xiong, X., et al. 2010. Loss of Resources and Hurricane Experience as Predictors of Postpartum Depression Among Women in Southern Louisiana. Journal of Women's Health. 19(5): 877-884.

30 Kilmer, R. P.; Gil-Rivas, V. 2010. Responding to the Needs of Children and Families after a Disaster: Linkages Between Unmet Needs and Caregiver Functioning. American Journal of Orthopsychiatry. 80(1):135-142.

31 Davis, T. E; Grills-Taquechel, A. E.; Ollendick, T. H. 2010. The Psychological Impact from Hurricane Katrina: Effects of Displacement and Trauma Exposure on University Students. Behavior Therapy. 41(3): 340-349.

32 Lau, J. F. T.; Yu, X.; Zhang, J., et al. 2010. Psychological Distress among Adolescents in Chengdu, Sichuan at 1 Month after the 2008 Sichuan Earthquake. Journal of Urban Health: Bulletin of the New York Academy of Medicine. 87(3): 504-523.

33 Cepeda A.; Saint Onge J. M.; Kaplan, C., et al. 2010. The Association Between Disaster-Related Experiences and Mental Health Outcomes Among Drug Using African American Hurricane Katrina Evacuees. Community Mental Health Journal. 46(6): 612-620.

34 Wind, T. R.; Fordham, M.; Komproe, I. H. 2011. Social Capital and Post-Disaster Mental Health. Global Health Action. 4: 1654-9880.

35 Irmansyah I.; Dharmono S.; Maramis, A., et al. 2010. Determinants of Psychological Morbidity in Survivors of the Earthquake and Tsunami in Aceh and Nias. International Journal of Mental Health Systems. 4: 1752-4458.

36 Ehrlich, M.; Harville, E.; Xiong, X., et al. 2010. Loss of Resources and Hurricane Experience as Predictors of Postpartum Depression Among Women in Southern Louisiana. Journal of Women's Health. 19(5): 877-884. 
Šios vienuolika stresorių grupių apima tokias pragmatiškas sritis kaip ekonominès problemos ar resursų praradimas. Kiti antriniai stresoriai yra daugiau psichologiniai ar socialiniai. Jie atspindi El paveiktų žmonių pačių savęs ar pasaulio aplinkos suvokimą.

Apibendrinant galima pasakyti, kad kiekvienas EI sukelia pirminius stresorius, kurie daro tiesiogini poveiki nukentejusiojo psichikos sveikatai. Besitęsiantys pirminiai stresoriai gali tapti antriniais. Antrinius stresorius gali sukelti ir pats ekstremalusis įvykis. Šie antriniai stresoriai sustiprina pirminiu stresorių poveikị ir taip pat gali sukelti psichikos sveikatos sutrikimus. Psichikos sveikatos būklę veikia ne tik pirminiai ir antriniai stresoriai, bet ir kiti gyvenimo ìvykiai, taip pat psichikos sveikatos būklè iki E[̨ $I^{37}$. Būtent todèl psichosocialinio atsako planavimas turètų būti šių planų integrali dalis, kuri būtina užtikrinant efektyvų ir koordinuotą atsaką visuomenės psichikos sveikatai įvykus EI . Planavimas psichikos sveikatos srityje padeda maksimaliai išnaudoti sistemos galimybes, personalo ir kitus išteklius teikiant psichikos sveikatos pagalbą išgyvenusiesiems, ESV darbuotojams ir bendruomenei ${ }^{38}$.

\section{Psichikos sveikatos sutrikimų dėl ekstremaliųjų ịvykių prevencija ir pagalbos teikimas po ju}

Daugelis organizacijų ir valstybės institucijų turi ekstremaliųjų situacijų valdymo planus (ESVP). Psichosocialinio atsako planavimas turètų būti šių planų integrali dalis, kuri būtina užtikrinant efektyvų ir koordinuotą atsaką visuomenès psichikos sveikatai ịvykus EĮ. Psichikos sveikatos pagalba išgyvenusiesiems jau turi būti pradèta teikti prieglaudose ar maisto išdavimo punktuose, kur renkasi nukentejjusieji po EĮ. Dažnai šios veiklos būna koordinuojamos Raudonojo Kryžiaus ar kitų organizacijų kartu su socialines paslaugas teikiančiomis organizacijomis, todèl svarbu, kad vietinès psichikos sveikatos institucijos bendradarbiautų ir su nevyriausybinemis organizacijomis, kurios teiktų psichikos sveikatos pagalbą. Ilgalaikè psichikos sveikatos pagalba turètų būti integruota $\mathfrak{i}$ kitas programas, skirtas išgyvenusiesiems EĮ. Psichikos sveikatos paslaugos išgyvenusiesiems taip pat gali būti teikiamos ligoninèse ar kitose medicinos ịstaigose. Taigi planuojant psichikos sveikatos pagalbos teikimą svarbi koordinacija ir integracija su kitomis valstybinemis institucijomis ir bendruomeninemis organizacijomis ${ }^{39}$.

Lock, S., supra note 20, p. 4.

38 New Jersey Department of Human Services, Division of Mental Health and Hospitals. Mental Health/Emergency Disaster Plan. Newark, NJ: 1991.

39 Hiley-Young, B.; Meyers, D. 1996. Disaster Response and Recovery: A Handbook for Mental Health Professionals. DIANE Publishing. 
Deja, dažnai ị ekstremaliųjų situacijų operacijų centro (ESOC) sudètį nebūna numatyta ittraukti psichikos sveikatos specialisto, tačiau rekomenduojama, kad bent jau ekstremaliųjų situacijų valdymo planuose (ESVP) būtų numatytas psichikos sveikatos specialistas, kuris išmanytų katastrofų psichikos sveikatą ir galètų priimti sprendimus dèl psichikos sveikatos teikimo EI metu ir po jo. Jis taip pat turètų išmanyti, kaip veikia psichikos sveikatos sistema šalyje ir kaip vyksta tarpinstitucinis bendradarbiavimas. Psichikos sveikatos specialistas turètų būti atsakingas už prioritetų nustatymą, resursų paskirstymą, veiksmų koordinavimą su kitomis tarnybomis ir patarimų teikimą ESOC vadovui ${ }^{40}$.

Dažniausiai stokojama psichikos sveikatos specialistų, kurie teiktų pagalbą El metu ${ }^{41}$. PSO siūlo keletą būdų, kaip pagerinti psichikos sveikatos priežiūros prieinamumą ${ }^{42}$. Pirmiausia siūloma psichiatrijos praktinį dèstymą įtraukti ị medicinos studentų studijų programą. Labai efektyvios yra ir trumpos psichikos sveikatos edukacinès programos nespecialistams: socialiniams darbuotojams, slaugytojoms ir kitiems medicinos ịstaigų darbuotojams. Taip pat siūloma praplèsti psichikos pagalbos teikimą ịtraukiant savanorius, šeimos narius ir kitų sektorių darbuotojus: mokytojus, policininkus ar religinius lyderius. Taip psichikos sveikatos priežiūra integruojama į visuomenès sveikatos sistemą ${ }^{43}$.

Ypač svarbu, kad ESVP būtų lankstūs, patikrinti ir nuolatos atnaujinami. Tam reikalingi adekvatūs ištekliai ir pasirengimas. Labai svarbu, kad asmenys, kurie dalyvaus veiksmuose atsakant $\dot{i} \mathrm{E}$, turètų aiškų supratimą apie savo vaidmeni ekstremaliojo įvykio metu ${ }^{44}$. Vienas geriausių pavyzdžių, kad EI planavimas ir pasirengimas yra efektyvus, galètų būti Kamaishi miesto Japonijoje moksleivių išsigelbėjimas nuo $2011 \mathrm{~m}$. smogusio galingo cunamio. Katastrofos metu visi mokykloje buvę vaikai buvo sèkmingai evakuoti, o mokykla netrukus buvo nušluota nuo žemès paviršiaus. Vèliau paaiškèjo, kad evakuacija buvo sẻkminga būtent todèl, kad nuo $2005 \mathrm{~m}$. bendradarbiaujant su profesoriumi T. Katada moksleiviams ir personalui buvo nuolat vykdomi mokymai ir treniruotes ${ }^{45}$.

$40 \quad$ Hiley-Young, B.; Meyers, D. 1996. Disaster Response and Recovery: A Handbook for Mental Health Professionals. DIANE Publishing.

${ }^{41}$ Murthy, R. S. 2005. Human Resources for Mental Health: Challenges and Opportunities in Developing Countries. International Psychiatry. 2: 5-7.

42 World Health Organization. Mental Health Assistance to the Populations Affected by the Tsunami in Asia [žiūrèta 2014-06-02]. <http://www.who.int/mental_health/resources/tsunami/en/index1. html>.

43 Jacob, K. S.; Sharan, P.; Mirza, I., et al. 2007. Mental Health Systems in Countries: Where are We Now? The Lancet. 370(9592): 1061-1077.

44 Bisson, J. I.; Cohen, J. A. 2006. Disseminating Early Interventions following Trauma. Journal of Traumatic Stress. 19: 583-95.

45 Yun, N. Y.; Hamada, M. 2011. A Comparative Study on Human Impacts caused by the 2011 Great East Japan Earthquake and Disaster Mitigation. In International Symposium on Engineering Lessons Learned from the. 
Vienas arčiausiai Lietuvos įvykusių teigiamo planavimo ir pasirengimo EI pavyzdžių galètų būti Švedijos pavyzdys po $1994 \mathrm{~m}$. įvykusios Estijos keleivinio kelto „MV Estonia“ katastrofos. Švedijos ligoninių ir psichikos sveikatos centru specialistai veikè labai operatyviai. Ligoninès Stokholmo srityje buvo pasirengusios teikti neatidèliotiną pagalbą EI metu, nes per prieš pat nelaimę vykusias pratybas kaip tik buvo imituotas panašus incidentas Baltijos jūroje. Pratybose igyti psichosocialiniai igūdžiai buvo pritaikyti padedant nukentejjusiesiems tikroje katastrofoje. Švedijos Ersta miesto psichiatrijos klinikoje buvo pradètos kurti krizès ịveikimo grupès nukentejusiųjų ar žuvusiųjų giminaičiams ${ }^{46}$. Tai tik keletas pavyzdžių, patvirtinančių, kad svarbu ne tik turèti ekstremaliųjų situacijų planus, bet ir mokèti juos taikyti praktiškai. Vien tik ESVP turejimas toli gražu neužtikrina, kad, susidarius ekstremaliajai situacijai, jie veiks sklandžiai.

\subsection{Psichikos sveikatos pagalbos prieinamumas po ekstremaliojo įvykio}

Sveikatos apsaugos sistemos atsakas i psichikos sveikatos problemas po EI turi būti aktyvus, tačiau tam gali kilti ịvairių kliūčių. C. Feltono ${ }^{47}$ straipsnyje nagrinejamas psichikos sveikatos problemų sprendimas, kreipiantis pagalbos i specialistus. Telefonu buvo apklausti 2752 Niujorke gyvenantys suaugusieji praejjus 6 mèn. po rugsèjo 11-osios ịvykių. Respondentų buvo klausiama, ar kreipési ł̇ specialistus dèl emocinių problemų, ar dèl problemų, susijusių su alkoholio, narkotinių medžiagų vartojimu 6 mén. iki ir po įvykio. Taip pat jie buvo vertinami dèl tikètinos PTSS diagnozès. 15 proc. apklaustųjų buvo nustatytas galimas PTSS arba depresija. Tiriamųjų, turinčių minètų sutrikimų, grupejje daugiau buvo moterų, 25-45 m. amžiaus žmonių arba žmonių, praeityje turejjusių psichikos sveikatos sutrikimų, taip pat nesusituokusiųjų ir neturinčių sveikatos draudimo. Iš visų apklaustųjų 9 proc. kreipèsi pagalbos dèl psichikos sveikatos problemų per 6 mèn. po rugsejjo 11-osios ịvykių. Net 64 proc. apklaustųjų, turinčių galimą PTSS ar depresiją, nesikreipe tokios pagalbos, nepaisant to, kad net 70 proc. jų pažymėjo sumažèjusius kasdienės veiklos funkcinius gebejjimus.

Minètame tyrime analizuoti ir su pagalbos dèl psichikos sveikatos problemų teikimu susiję veiksniai. Specialistai daugiau konsultavo tuos asmenis, kurių metinès pajamos buvo didesnès nei 30 tūkst. dolerių, kurie buvo kreipęsi ị psichikos sveikatos specialistus iki rugsejjo 11-osios įvykių, turèjo nuolatini gydytoją arba buvo blogesnès bendros sveikatos būklès. Šis tyrimas atskleidè, kad psichikos sveikatos pagalba po EI teikiama nepakankamai, nors ir po rugsejo 11-osios ịvykių Niujorke buvo igyvendintas Laisvés projektas (angl. Liberty Project). Tai pre-

${ }_{46}$ Brandänge, K.; Gustavsson, J. P. 2000. After the MV Estonia Ferry Disaster A Swedish Nationwide Survey of the Relatives of the MV Estonia Victims. Dialogues in Clinical Neuroscience. 2(1): 63.

47 Felton, C. 2002. Project Liberty: a Public Health Response to New Yorkers' Mental Health Needs Arising From the World Trade Center Terrorist Attacks. Journal of Urban Health. 79(3): 429-433. 
cedento neturinti programa, kurios tikslas buvo šviesti visuomenę apie reakcijas i traumuojamąji îvykị, teikti nemokamus su krize susijusius patarimus ir siųsti specializuoto psichikos sveikatos gydymo būtent tuos žmones, kuriems jo reikia.

Idomus radinys yra tas, jog turintieji fizinès sveikatos problemų sulauke daugiau pagalbos dèl psichikos sveikatos sutrikimų. Tai aiškintina tuo, kad jie jau turi ryší su sveikatos apsaugos sistema ir lengviau prieina prie psichikos sveikatos $\operatorname{tarnybų~}^{48}$. Be to, fizinès sveikatos problemos ženkliai sumažina funkcinius kasdienès veiklos gebėjimus ir skatina ieškoti pagalbos. Kartu aiškintini ir radiniai, jog asmenys, anksčiau turèję emocinių problemų, taip pat dažniau konsultavosi dèl psichikos sveikatos sutrikimų su specialistais po rugsėjo 11-osios įvykių. Šiame tyrime buvo nustatyti ir trukdžiai kreiptis pagalbos. Apklaustieji nurodè, jog jiems trūko žinių, kaip tą pagalbą gauti, buvo susirūpinę dẻl psichinès negalios stigmos, nurode pinigu ar laiko stoką. Dalis apklaustųjų nurodè altruistines priežastis - jie nesikreipė pagalbos, nes esą kitiems šios pagalbos reikejję labiau nei jiems patiems. Kiti pateikè ir papildomus paaiškinimus. Dažniausiai respondentai teigè, kad kreipiasi pagalbos ị šeimos narius ar draugus, dalis apklaustụjų pateikè ir retesnes priežastis: jautėsi per daug sugniuždyti, nepasitikèjo psichikos sveikatos specialistais ar bijojo pokalbio apie rugsèjo 11-osios vykius. Be abejo, šie tyrimo duomenys nè kiek nesumenkina Laisvès projekto programos pasiekimų, kuri suteikè patarimų 91 tūkst. žmonių ${ }^{49}$.

Psichikos sveikatos pagalbos prieinamumas buvo pakankamai efektyvus ir Švedijoje po 1994 m. Estijos keleivinio kelto „MV Estonia“ katastrofos. Vienoje psichiatrijos klinikoje buvo pradètos kurti krizių grupės nukentejjusiųjų ar žuvusiųjų giminaičiams ${ }^{50}$.

$2004 \mathrm{~m}$. kovo $11 \mathrm{~d}$. teroristai susprogdino bombas keturiuose Madrido (Ispanija) priemiestiniuose traukiniuose. Žuvo 191 žmogus, o dar 1,5 tūkst. buvo sužeisti. Po ịvykio buvo manoma, kad vaikams ir paaugliams nèra didelio psichosocialinès pagalbos poreikio, tačiau kai pagalbos komanda aktyviai pradẻjo lankyti netoli ịvykio vietos esančias mokyklas, vizitų i psichikos sveikatos centrus skaičius ryškiai išaugo. Paveiktiems vaikams dviejuose labiausiai nukentėjusiuose regionuose buvo ịkurti „popietiniai“ centrai, kurie veikè dar vienerius metus po itvykio ${ }^{51}$.

8 Felton, C. 2002. Project Liberty: a Public Health Response to New Yorkers' Mental Health Needs Arising From the World Trade Center Terrorist Attacks. Journal of Urban Health. 79(3): 429-433.

49 Felton, C., supra note, 45, p. 429-433.

$50 \quad$ Brandänge, K.; Gustavsson, supra note, 44, p. 63.

51 Boiling, R.; Ehrlin, Y.; Forsberg, R., et al. 2007. KAMEDO Report 90: Terrorist Attacks in Madrid, Spain, 2004. Prehospital and Disaster Medicine. 22(03): 252-257. 
2.2. Bendrieji psichikos sveikatos pagalbos teikimo principai ekstremaliujų situacijų metu

Žmogaus teisių pažeidimas teikiant psichosocialinę pagalbą nuo EI nukentẻjusiesiems, negebejimas specifiškai veikti skirtingose kultūrose, atsižvelgiant $\mathfrak{i}$ etninius ir kultūrinius nukentejjusiųjų skirtumus, gali didinti psichikos sveikatos problemas. Taigi visos psichikos sveikatos intervencinès programos turi būti kuriamos vadovaujantis tarptautinèmis gairèmis ir dokumentais, būtinai atsižvelgiant ị žmogaus teises. Būtent todèl ịvairios tarptautinès agentūros ir organizacijos vis labiau sutaria dèl geros praktikos principų teikiant medicinos ir psichosocialinę pagalbą nukentejusiesiems nuo įvairių Eİ. 2007 m. buvo paskelbtos vadinamosios IASC ${ }^{52}$ gairès apie psichikos sveikatą ir psichosocialinę pagalbą esant ekstremaliosioms situacijoms. Šias gaires parengè praktikai iš skirtingu geografinių regionų, disciplinų ir sektorių. Tai atspindi bendrą profesionalų sutarimą ir susivienijimą tikslui pasiekti. Pagrindinè šių gairių idejja - tai būtinybė ankstyvoje ekstremaliojo ịvykio fazejje užtikrinti socialinę paramą, siekiant užtikrinti psichikos ir psichosocialinès sveikatos gerovę. Šiose gairèse taip pat rekomenduojamos atskiros psichologinès ir psichiatrinès intervencijos specifinèms problemoms spręsti.

Minètos gairès remiasi šiais pagrindiniais principais:

- žmonių teisèmis ir lygybe;

- nukentejusiųjų įtraukimu;

- siekiu pirmiausia nepakenkti;

- vietinių resursų mobilizavimu;

- bendruomenès ir ịvairių tarnybų integruotu atsaku ị ekstremaliąją situaciją;

- daugiasluoksne psichosocialine pagalba esant ekstremaliosioms situacijoms (nuo bendruomeninès psichosocialinès paramos iki specializuotos pagalbos).

Taigi ekstremaliųjų įvykių metu tiek medicinos, tiek visuomenès sveikatos pagalba turi būti teikiama laikantis tarptautinès humanitarinès teisès ir etikos normų. Tokias normas daugiau nei 200 nevyriausybinių organizacijų yra patvirtinę kaip „Sferos projektą “" ${ }^{\text {"S3 }}$. Šiame projekte pateikiami minimalūs reikalavimai teikiant humanitarinę pagalbą, jis išverstas į daugiau kaip 20 kalbų. „Sferos projekto" standartą sudaro 12 požymių, kurie suskirstyti ị socialinès ir psichologinès intervencijos rodiklius.

52 IASC. 2007. IASC Guidelines on Mental Health and Psychosocial Support in Emergency Settings. Geneva: Inter-Agency Standing Committee.

53 Sphere Project. 2004. Humanitarian Charter and Minimum Standarts in Disaster Response. Geneva: Sphere Project. 
Teikiant pagalbą turi būti laikomasi šių socialinès intervencijos rodiklių:

1) nukentejusieji turi gauti patikimą informaciją apie EĮ ir su juo susijusios pagalbos teikimą;

2) iprasti kultūriniai ir religiniai ritualai neturi būti nutraukti arba kuo greičiau atkurti;

3) vaikai ir paaugliai kuo greičiau turi grịžti ị mokyklas, kai tik tai ịmanoma (atkūrus resursus);

4) suaugusieji ir paaugliai turi būti ịtraukti ị gelbejjimo darbus;

5) izoliuoti asmenys, tokie kaip atsiskyrę ar našlaičiais likę vaikai, našlès ir našliai, vyresni žmonès turi būti įtraukti ị socialines veiklas;

6) turi būti suorganizuota tarnyba, padedanti susijungti žmonèms ir šeimoms;

7) jeigu nukentejjusieji paliko savo gyvenamąją vietą, turi būti organizuojami laikini būstai, siekiant išlaikyti šeimų narius ir bendruomenes kartu;

8) turi būti tariamasi su bendruomene, kur ịkurdinti religines vietas, mokyklas, vandens išdavimo punktus ir sanitarinius įrenginius;

Teikiant pagalbą turi būti laikomasi šių psichologinès intervencijos rodiklių:

1) asmenims, kuriems pasireiške ūminis psichikos sutrikimas po EIt, turi būti suteikta pirmoji psichologinè pagalba;

2) ūminiai psichiatriniai sutrikimai turi būti gydomi pirminèje sveikatos priežiūros grandyje. Pirminès sveikatos priežiūros ịstaigose būtinųjų vaistų sąrašuose turi būti pagrindinių psichiatrinių vaistų;

3) asmenims, sergantiems psichiatrinèmis ligomis, turi būti užtikrintas nenutrūkstamas gydymas;

4) sudaromi ilgalaikiai ị bendruomenę orientuoti psichologinès pagalbos planai.

Teikiant humanitarinę pagalbą negalima skirstyti žmonių pagal jų tautybę, rasę, religiją, socialinę grupę ar politines pažiūras. Bet kokia diskriminacija yra griežtai draudžiama. Humanitarinès pagalbos esmė yra padėti žmonėms tiek, kiek jiems reikia, pirmenybę teikiant skubiausiems atvejams. Resursai skirstomi pagal principą, kad „vienoda kančia reikalinga vienodos pagalbos“汭. Teikiančioms humanitarinę pagalbą organizacijoms būtina laikytis neutralumo principo - neįsitraukti į politinius, rasinius, religinius ar ideologinius prieštaravimus. Šios organizacijos turi veikti autonomiškai. Pagalbą teikiančios organizacijos turi pačios priiminèti sprendimus - tai pats efektyviausias būdas veikti.

54 Thurer D. 2007. Dunant's Pyramid: Thoughts on the „Humanitarian Space.“ Intl Rev Red Cross., 89: 47-61. 


\subsection{Ekstremaliųjų situacijų valdyme dalyvaujančių institucijų kompetencijos}

Katastrofų medicinos ir visuomenès sveikatos srityje labai svarbu paskirstyti kompetencijas ir išsiugdyti personalą, kuris turètų gebejjimų, ịgūdžių ir žinių dalyvauti visame EI valdymo cikle ${ }^{55}$. Ivairių sričių specialistai turi būti išskirti i skirtingus kompetencijų lygius katastrofų medicinos visuomenès sveikatos srityje. Šios kompetencijos siejasi su jų numatomu vaidmeniu įvykus katastrofai. Kai kurios organizacijos, kaip antai Katastrofų medicinos ir visuomenės sveikatos nacionalinis centras JAV, tokias kompetencijas suskirste hierarchine tvarka ì piramidę. Piramidès pagrindą sudaro institucijos, organizacijos ir agentūros, kuriose dirba sveikatos specialistai, privalantys turèti katastrofų medicinos žinių. Aukštesnị lygị sudaro sveikatos disciplinos ir profesijos, kurios reikalingos specialių žinių ir gebejjimų. Piramidès viršūnèje esti labai savitos kompetencijos, kurias privalo turèti sveikatos apsaugos darbuotojai, sudarantys įvairias atsako ị E[ komandas. Taigi ši piramidè rodo kompetencijų pasiskirstymą nuo pagrindinių iki labai specializuotų. Efektyvus pasiruošimas, atsakas ir atsikūrimas po EI reikalingi gerai suplanuotų ir integruotų patyrusių specialistų pastangų, galinčių pritaikyti savo žinias ir igūdžius esant kritinems situacijoms $s^{56}$.

EI sukelia pažeistos populiacijos dezintegraciją ir sutrikdo normalų jos funkcionavimą. EI žalos mastas visuomeneje yra labai glaudžiai susijęs su pasirengimu galimam pavojingam ịvykiui. Visuomenès pasirengimas, reagavimas ir atsigavimo / atsikūrimo procesai po patirtos nelaimès vyksta jų bendruomenès, šalies sociopolitiniame ir kultūriniame kontekste. Kai kurios kultūrinès grupès, šalys dažnai nesiruošia tokiems įvykiams dèl finansavimo stokos. Taigi kai kurių bendruomenių nariai yra nepakankamai pasiruošę ekstremaliosioms situacijoms. Lyginant su besivystančiomis šalimis, išsivysčiusios šalys linkusios geriau pasirengti galimiems EI iš anksto, taip sušvelnindamos nelaimès mastą. Psichikos sveikatos programos nuo pat pradžiu privalo nusitaikyti ị ilgalaiki psichikos sveikatos paslaugų vystymą. Tradiciškai daugiau dėmesio skiriama greitai ir trumpalaikei psichikos sveikatos sutrikimų korekcijai ūminėje EI fazéje. Ilgalaikiai tikslai, koreguojant psichikos sveikatos sutrikimus, pabrèžiami ir PSO pranešime, skirtame psichikos sveikatai ${ }^{57}$. Šiame dokumente taip pat akcentuojama konsultavimosi ir bendradarbiavimo tarp vyriausybinių ir nevyriausybinių organizacijų svarba; psichikos sveikatos intervencijų integravimas ị pirmi-

55 Walsh, L.; Subbarao, I.; Gebbie, K., et al. 2012. Core Competencies for Disaster Medicine and Public Health. Disaster Medicine and Public Health Preparedness. 6(1): 44-52.

56 Subbarao, I.; Lyznicki, J. M.; Hsu, E. B., et al. 2008. A Consensus-based Educational Framework and Competency Set for the Discipline of Disaster Medicine and Public Health Preparedness. Disaster Medicine and Public Health Preparedness. 2(1): 57-68.

57 WHO. 2003. Mental Health in Emergencies: Mental and Social Aspects of Health of Populations Exposed to Extreme Stressors. Geneva: World Health Organization. 
nės sveikatos priežiūrą (PSP), prièjimo prie psichikos sveikatos paslaugų visiems užtikrinimas, vengiant vertikalių tarnybų kūrimo, skirtų specialioms populiacijoms; asmenų, dirbančių PSP, mokymas ir priežiūra bei situacijos stebèsena.

Ilgalaikiai tikslai reikalingi pradinès situacijos analizès apie psichikos sveikatos tarnybas EĮ zonoje. Analizė turi apimti esamų resursų ištyrimą, tokių kaip visuomeninès organizacijos, religinès institucijos, tradiciniai gydytojai. Tai gali padèti intervencijoms pradinéje fazėje ir suformuoti bendrą atsaką psichikos sveikatai gerinti EI zonoje. Didžiosios tarptautinès direktyvos nurodo, kad psichikos sveikatos tarnybos turi būti integruotos ị PSP tarnybas $s^{58},{ }^{59}$. PSP tarnyba yra pagrindinis taškas sveikatos apsaugos sistemoje, kur konsultuojami pacientai. Pagrindinis PSP tikslas yra ligų profilaktika, dažniausių ligų gydymas ir esamų sveikatos problemų valdymas. Priklausomai nuo šalies sveikatos apsaugos sistemos PSP tarnyboje pagrindinị vaidmeni gali atlikti gydytojas, slaugytojas, sveikatos priežiūros darbuotojas ar netgi bendruomenès nariai. Visuomenės psichikos sveikatos centrai ir psichikos sveikatos tarnybos prie didžiųjų ligoninių turi vadovauti mokymams ir priežiūrai, kurie yra būtini sẻkmingam psichikos sveikatos integravimui į PSP.

PSO duomenimis, 70 proc. šalių turi nacionalines psichikos sveikatos programas, 55 proc. turi tam tikrų priemonių gydyti psichikos sutrikimams PSP istaigose ir 62 proc. turi bendruomeninių tarnybu psichikos sveikatos problemoms spręsti ${ }^{60}$. Tačiau reikia atsižvelgti ị tai, kad plano ar patalpų turëjimas dar nereiškia, kad bus lèšų ir kad tas planas bus igyvendintas ${ }^{61}$.

\section{Išvados ir siūlymai}

Prisitaikant prie nuolat kintančios saugumo aplinkos ir mokantis iš patirties, ieškoma ir pasiūloma vis daugiau modelių, kaip reaguoti ị neigiamai psichikos sveikatą veikiančius įvykius. Visuomenès atsakas ị šiuos ịvykius formuojamas naudojant medicininius, idejjinius, juridinius, religinius ir kitokius įrankius, taikomus pasitelkiant atitinkamas institucijas ir / ar neformalias socialinės komunikacijos struktūras. Požiūris ị ekstremaliųjų ịvykių sukeltus psichikos sveikatos sutrikimus labai kito. Kitados šie nukrypimai buvo laikyti labai retais, ir tik XX a. pabaigoje šis požiūris pasikeitè. Potrauminis stresas ir po jo išsivystęs

\footnotetext{
58 IASC-RG. 2010. Mental Health and Psychosocial Support in Humanitarian Emergencies: What Should Humanitarian Health Actors Know? Israeli Journal of Psychiatry. Geneva: IASC Reference Group for Mental Health and Psychosocial Support in Emergency Settings.

59 WHO \& Wonca. 2008. Integratingmental Health into Primary Care: A Global Perspective. Geneva: World Health Organisation.

60 WHO. 2005. Health and climate change: The Now and How. A Policy Action Guide, World Health Organization Regional Office for Europe. Copenhagen: World Health Organization.

${ }_{61}$ Petersen, I.; Lund, C.; Stein, D. J. 2011. Optimizing Mental Health Services in Low-income and Middle-income Countries. Current Opinion in Psychiatry. 24(4): 318-323.
} 
nuolatinis patologinis atsakas ị šį stresą mokslo pripažinti kaip dažnas reiškinys. Tačiau šie sutrikimai tebekelia daug prieštaringų diskusijų ir vertinimų. Pasigirsta nuomonių, kad reikia radikaliai keisti požiūrị i̇ potrauminio streso sindromą ir vertinti ji ne medicininiu, bet politiniu ir makrosocialiniu požiūriu.

Planuojant atsako ị ekstremaliuosius ịvykius priemones, būtina užtikrinti psichikos sveikatos tarnybų prieinamumą ir psichosocialinę paramą nukentèjusioms bendruomenèms. İvairios tarptautinès agentūros ir organizacijos vis geriau sutaria dèl geros praktikos principų teikiant medicinos ir psichosocialinę pagalbą nukentejjusiesiems nuo ịvairių EĮ. Šie principai sudaro palankias sąlygas plètoti gerąją patirtị, išvengti diskriminacijos ir kitų žmogaus teisių pažeidimų teikiant humanitarinę pagalbą.

Dèl ekstremaliųjų situacijų neapibrèžtumo svarbu, kad ekstremaliųjų situacijų valdymo planai būtų lankstūs, patikrinti ir nuolatos atnaujinami. Tam reikalingi adekvatūs ištekliai ir pasirengimas. Asmenys, kurie dalyvaus veiksmuose atsakant į EIt, turi aiškiai suvokti ir būti tinkamai pasiruošę vykdyti jiems nustatytas užduotis tokių îvykių metu. Pasirengimo ekstremaliosioms situacijoms planuose turètų būti ịvertintas psichikos sveikatos ir psichosocialinès paramos poreikis, numatyta, kokios tarnybos užtikrins psichologinę paramą žmonėms, turintiems psichikos sveikatos sutrikimų (tiek buvusių iki ekstremaliojo įvykio, tiek sukeltų Eİ) bei gelbejjimo veiksmus atliekantiems darbuotojams ir savanoriams.

EI žalos mastas visuomenèje yra labai glaudžiai susijęs su pasirengimu pavojingiems ịvykiams. Psichikos sveikatos sutrikimams išsivystyti labai svarbus ne tik pats El, bet ir rizikos veiksniai. Visuomenés pasirengimas, reagavimas ir atsigavimo / atsikūrimo procesai po patirtos masinès nelaimès vyksta jų bendruomenès, šalies sociopolitiniame ir kultūriniame kontekste. Efektyviai veiklai užtikrinti tikslinga sudaryti ilgalaikę bendruomenès psichikos sveikatos priežiūros sistemą po Eİ, atsižvelgiant ị konkrečios bendruomenės/ visuomenės bei jų aplinkos charakteristikas. Katastrofų medicinos ir visuomenès sveikatos srityje paskirstyti kompetencijas ir išsiugdyti personalą, kuris turètų gebejjimų, igūdžiu ir žinių dalyvauti visame EI valdymo cikle. İvairių sričių specialistai turètų paskirstyti pagal kompetencijų lygius katastrofų medicinos visuomenès sveikatos srityje. Šios kompetencijos siejasi su jų numatomu vaidmeniu ịvykus nelaimei.

\section{Literatūra}

1. Ahern, J.; Galea, S.; Resnick, H., et al. 2002. Television Images and Psychological Symptoms after the September 11 Terrorist Attacks. Psychiatry. 65: 289-300.

2. American Psychiatric Association. 2013. The Diagnostic and Statistical Manual of Mental Disorders: DSM 5. Bookpoint US. 
3. Berger, W.; Coutinho, E. S.; Figueira, I., et al. 2012. Rescuers at Risk: A Systematic Review and Meta-regression Analysis of the Worldwide Current Prevalence and Correlates of PTSD in Rescue Workers. Social Psychiatry and Psychiatric Epidemiology. 47(6): 1001-1011.

4. Bisson, J. I.; Cohen, J. A. 2006. Disseminating Early Interventions following Trauma. Journal of Traumatic Stress. 19: 583-95.

5. Boiling, R.; Ehrlin, Y.; Forsberg, R., et al. 2007. KAMEDO Report 90: Terrorist Attacks in Madrid, Spain, 2004. Prehospital and Disaster Medicine. 22(03): 252-257.

6. Boscarino, J. A. 2008. Prospective Study of PTSD and Early-age Heart Disease Mortality among Vietnam Veterans: Implications for Surveillance and Prevention. Psychosomatic Medicine. 70: 668.

7. Brandänge, K.; Gustavsson, J. P. 2000. After the MV Estonia Ferry Disaster A Swedish Nationwide Survey of the Relatives of the MV Estonia Victims. Dialogues in Clinical Neuroscience. 2(1): 63.

8. Carroll, B.; Balogh, R.; Morbey, H., et al. 2010. Health and Social Impacts of a Flood Disaster: Responding to Needs and Implications for Practice. Disasters. 34(4): 1045-63.

9. Cepeda A.; Saint Onge J. M.; Kaplan, C., et al. 2010. The Association Between Disaster-Related Experiences and Mental Health Outcomes Among Drug Using African American Hurricane Katrina Evacuees. Community Mental Health Journal. 46(6): 612-620.

10. Ciscar, J. C.; Iglesias, A.; Feyen, L., et al. 2011. Physical and Economic Consequences of Climate Change in Europe. Proceedings of the National Academy of Sciences of USA. 108: 2678-2683.

11. Creamer, M.; Burgess, P.; McFarlane, A. C. 2001. Post-traumatic Stress Disorder: Findings from the Australian National Survey of Mental Health and Well-being. Psychological Medicine. 31(07): 1237-1247.

12. Darves-Bornoz, J. M.; Alonso, J.; de Girolamo, G., et al. 2008. Main Traumatic Events in Europe: PTSD in the European Study of the Epidemiology of Mental Disorders Survey. Journal of Traumatic Stress. 21(5): 455-462.

13. Davis, T. E; Grills-Taquechel, A. E.; Ollendick, T. H. 2010. The Psychological Impact from Hurricane Katrina: Effects of Displacement and Trauma Exposure on University Students. Behavior Therapy. 41(3): 340-349.

14. Duke, L. M.; Vasterling, J. J. 2005. Epidemiological and Methodological Issues in Neuropsychological Research in PTSD. In: Vasterling, J.J., Brewin, C.R. (Eds.) Neuropsychology of PTSD: Biological, Cognitive, and Clinical Perspective. New York: The Guilford Press.

15. Ehrlich, M.; Harville, E.; Xiong, X., et al. 2010. Loss of Resources and Hurricane Experience as Predictors of Postpartum Depression Among Women in Southern Louisiana. Journal of Women's Health. 19(5): 877-884.

16. Ehrlich, M.; Harville, E.; Xiong, X., et al. 2010. Loss of Resources and Hurricane Experience as Predictors of Postpartum Depression Among Women in Southern Louisiana. Journal of Women's Health. 19(5): 877-884.

17. Ehrlich, M.; Harville, E.; Xiong, X., et al. 2010. Loss of Resources and Hurricane Experience as Predictors of Postpartum Depression Among Women in Southern Louisiana. Journal of Women's Health. 19(5): 877-884. 
18. Felton, C. 2002. Project Liberty: a Public Health Response to New Yorkers' Mental Health Needs Arising From the World Trade Center Terrorist Attacks. Journal of Urban Health. 79(3): 429-433.

19. Galea., S.; Nandi, A.; Vlahov, D. 2005. The Epidemiology of Post-Traumatic Stress Disorder after Disasters. Oxford Journals Medicine Epidemiologic Reviews. 27(1): 78-91.

20. Green, B. L.; Lindy, J. D.; Grace, M. C., et al. 1990. Buffalo Creek Survivors in the Second Decade: Stability of Stress Symptoms. American Journal of Orthopsychiatry. 60: 43-54.

21. Hiley-Young, B.; Meyers, D. 1996. Disaster Response and Recovery: A Handbook for Mental Health Professionals. DIANE Publishing.

22. IASC. 2007. IASC Guidelines on Mental Health and Psychosocial Support in Emergency Settings. Geneva: Inter-Agency Standing Committee.

23. IASC-RG. 2010. Mental Health and Psychosocial Support in Humanitarian Emergencies: What Should Humanitarian Health Actors Know? Israeli Journal of Psychiatry. Geneva: IASC Reference Group for Mental Health and Psychosocial Support in Emergency Settings.

24. Irmansyah I.; Dharmono S.; Maramis, A., et al. 2010. Determinants of Psychological Morbidity in Survivors of the Earthquake and Tsunami in Aceh and Nias. International Journal of Mental Health Systems. 4: 1752-4458.

25. Yehud, R.; Hallig, S. L.; Grossman, R. 2001. Childhood Trauma and Risk for PTSD: Relationship to Intergenerational Effects of Trauma, Parental PTSD, and Cortisol Excretion. Development and Psychopathology. 13: 733-753.

26. Yun, N. Y.; Hamada, M. 2011. A Comparative Study on Human Impacts caused by the 2011 Great East Japan Earthquake and Disaster Mitigation. In International Symposium on Engineering Lessons Learned from the.

27. Jacob, K. S.; Sharan, P.; Mirza, I., et al. 2007. Mental Health Systems in Countries: Where are We Now? The Lancet. 370(9592): 1061-1077.

28. Kessler, R. C.; Berglund, P.; Delmer, O., et al. 2005. Lifetime prevalence and ageof-onset distributions of DSM-IV disorders in the National Comorbidity Survey Replication. Archives of General Psychiatry. 62(6): 593-602.

29. Kilmer, R. P.; Gil-Rivas, V. 2010. Responding to the Needs of Children and Families after a Disaster: Linkages Between Unmet Needs and Caregiver Functioning. American Journal of Orthopsychiatry. 80(1):135-142.

30. Lau, J. F. T.; Yu, X.; Zhang, J., et al. 2010. Psychological Distress among Adolescents in Chengdu, Sichuan at 1 Month after the 2008 Sichuan Earthquake. Journal of Urban Health: Bulletin of the New York Academy of Medicine. 87(3): 504-523.

31. Lock, S.; Rubin, G. J.; Murray, V., et al. 2012. Secondary Stressors and Extreme Events and Disasters: a Systematic Review of Primary Research from 2010-2011. PLoS Currents. 4.

32. Maia, D. B.; Marmar, C. R.; Metzler, T., et al. 2007. Post-traumatic Stress Symptoms in an Elite Unit of Brazilian Police Officers: Prevalence and Impact on Psychosocial Functioning and on Physical and Mental Health. Journal of Affective Disorders. 97(1): 241-245. 
33. Mitchell, T. L.; Griffin, K.; Stewart, S. H., et al. 2004. We Will Never Ever Forget: The Swissair Flight 111 Disaster and its Impact on Volunteers and Communities. Health Psychology. 9(2): 245-62.

34. Murthy, R. S. 2005. Human Resources for Mental Health: Challenges and Opportunities in Developing Countries. International Psychiatry. 2: 5-7.

35. New Jersey Department of Human Services, Division of Mental Health and Hospitals. Mental Health/Emergency Disaster Plan. Newark, NJ: 1991.

36. North, C. S.; Oliver, J.; Pandya, A. 2012. Examining a comprehensive model of disaster-related posttraumatic stress disorder in systematically studied survivors of 10 disasters. American Journal of Public Health. 102(10): e40-e48.

37. Penalba, V.; McGuire, H.; Leite, J. R. 2008. Psychosocial Interventions for Prevention of Psychological Disorders in Law Enforcement Officers. Cochrane Database of Systematic Reviews., 3.

38. Petersen, I.; Lund, C.; Stein, D. J. 2011. Optimizing Mental Health Services in Lowincome and Middle-income Countries. Current Opinion in Psychiatry. 24(4): 318-323.

39. Sphere Project. 2004. Humanitarian Charter and Minimum Standarts in Disaster Response. Geneva: Sphere Project.

40. Subbarao, I.; Lyznicki, J. M.; Hsu, E. B., et al. 2008. A Consensus-based Educational Framework and Competency Set for the Discipline of Disaster Medicine and Public Health Preparedness. Disaster Medicine and Public Health Preparedness. 2(1): 57-68.

41. Thurer D. 2007. Dunant's Pyramid: Thoughts on the „Humanitarian Space.“ Intl Rev Red Cross., 89: 47-61.

42. Trautman, R.; Tucker, P.; Pfefferbaum, B., et al. 2002. Effects of Prior Trauma and Age on Posttraumatic Stress Symptoms in Asian and Middle Eastern Immigrants after Terrorism in the Community. Community Mental Health Journal. 38: 459-74.

43. United Nations: Rio Declaration: Rio+20 - The Future We Want. 2012. Rio de Janeiro: Rio 20 United Nations Conference on Sustainable Development.

44. Walsh, L.; Subbarao, I.; Gebbie, K., et al. 2012. Core Competencies for Disaster Medicine and Public Health. Disaster Medicine and Public Health Preparedness. 6(1): 44-52.

45. Wang, C. W.; Chan, C. L.; Ho, R. T. 2013. Prevalence and Trajectory of Psychopathology among Child and Adolescent Survivors of Disasters: a Systematic Review of Epidemiological Studies across 1987-2011. Social Psychiatry and Psychiatric Epidemiology. 48(11): 1697-1720.

46. WHO \& Wonca. 2008. Integratingmental Health into Primary Care: A Global Perspective. Geneva: World Health Organisation.

47. WHO. 2003. Mental Health in Emergencies: Mental and Social Aspects of Health of Populations Exposed to Extreme Stressors. Geneva: World Health Organization.

48. WHO. 2005. Health and climate change: The Now and How. A Policy Action Guide, World Health Organization Regional Office for Europe. Copenhagen: World Health Organization.

49. Wickrama, K. A. S.; Wickrama T. 2011. Perceived Community Participation in Tsunami Recovery Efforts and the Mental Health of Tsunami-Affected Mothers: Findings from a Study in Rural Sri Lanka. International Journal of Social Psychiatry. 57(5): 518-27. 
50. Wind, T. R.; Fordham, M.; Komproe, I. H. 2011. Social Capital and Post-Disaster Mental Health. Global Health Action. 4: 1654-9880.

51. Wind, T. R.; Fordham, M.; Komproe, I. H. 2011. Social Capital and Post-Disaster Mental Health. Global Health Action. 4: 1654-9880.

52. World Health Organization. 2012. Global Burden of Mental Disorders and the Need for a Comprehensive, Coordinated Response from Health and Social Sectors at the Country Level.

53. World Health Organization. 2013. Mental Health Action Plan 2013-2020.

54. World Health Organization. Mental Health Assistance to the Populations Affected by the Tsunami in Asia [žiūrèta 2014-06-02]. <http://www.who.int/mental_health/ resources/tsunami/en/index1.html>.

55. Zhang, Z.; Shi, Z.; Wang, L., et al. 2011. One Year Later: Mental Health Problems among Survivors in Hard-Hit Areas of the Wenchuan Earthquake. Public Health. 125(5): 293-300.

\title{
Significance of Mental Health Support after Disasters
}

\author{
Birutè Pitrènaitė-Žilènienè \\ Mykolas Romeris University, Lithuania \\ Vilma Miglinè \\ Vilnius City Public Health Bureau, Lithuania
}

Summary. It is forecasted that in the coming decades, Europe will inevitably be affected by very important natural and social upheavals, which can significantly affect public welfare, physical and mental health disorders. That is why it is important to prepare properly. In this context, the emphasis is to be able to effectively adapt to a rapidly changing world. Because of geophysical situation changes, a target would be to create a resistant society, which would be able to neutralize any upheaval impact and timely recover from it. War, armed conflicts, natural and technological disasters have a major psychological and social impact on the affected population. After each disaster, many people experience emotional trauma. Strong emotional upheaval can be experienced not only by those directly involved in the event and/or physical trauma victims, but also by their relatives or even an event unrelated individuals.

The purpose of this article is to analyze the current scientific literature, highlight the negative impact on the mental health of the risk factors during the emergency and substantiate the necessity to plan mental health related preventive measures.

One of the most common mental health problems after a disaster is a post-traumatic stress disorder (PTSD). Various factors may increase the risk of the development of the PTSD. Social factors play a significant role among them. Psychological resistance is strongly influenced by the perception that during emergency, support to the victims will be provided not only by family, but also by the competent authority which will properly take care of the physical and psychological comfort reset. That is why the emergency plans should include not only search, rescue and other means related to saving lives and physical health, but also means related to psychosocial support services. 
It is hardly possible to develop precise scenarios/prognosis of a disaster. Therefore, flexibility, regular checking and update are essential requirements for emergency management planning. Individuals who participate in actions in response to an emergency must have a clear understanding of their role. When planning a response to the disaster, it is necessary to ensure the availability of mental health services and psychosocial support to the affected communities, according to the risk factors, which influence the development of mental health disorders. Therefore, it is extremely important to create a long-term communitybased mental health care system for response during and recovery after disasters.

Keywords: mental health, disaster, post-traumatic stress disorder, risk factors, stressors, prevention.

Birutè Pitrènaitė-Žilènienė, Mykolo Romerio universiteto Politikos ir vadybos fakulteto Vadybos instituto profesorè, socialinių mokslų daktarè. Mokslinių tyrimų kryptys: viešasis saugumas, e. sveikata, suinteresuotųjų vadyba, socialinės technologijos viešajam valdymui.

Birutè Pitrènaitè-Žilènienė, Doctor of Social Sciences, Professor at the Institute of Management, Faculty of Politics and Management, Mykolas Romeris University. Research interests: public safety, e.Health, stakeholder management, social technologies in public sector.

Vilma Miglinė, Vilniaus miesto savivaldybės visuomenès sveikatos biuro visuomenès sveikatos stiprinimo vyriausioji specialistė, prevencinių programų koordinatorè.

Vilma Miglinè, Senior public official for public health promotion and coordination of preventive programs at Vilnius City Public Health Bureau. 